ISSN: 2515-6918, Online ISSN: 2515-6926

DOI: https://doi.org/10.1332/251569214X15664520275057

Volume 32 , Issue 1-3, pages 99-112

(C) AESP 2014

Go to section...

\title{
Public Governance and Productive Efficiency in Sub-Saharan Africa
}

Giampaolo Garzarelli-; Yasmina Rim Limam; Stefania P.S. Rossi

1: DiSSE, Sapienza - Università di Roma, Rome, ITALY \& IPEG, SEBS, University of the Witwatersrand, Johannesburg - SOUTH AFRICA; 2: Facult é des Sciences Économiques et de Gestion de Nabeul, Nabeul, TUNISIA \& IPEG, SEBS, University of the Witwatersrand, Johannesburg - SOUTH AFRICA; 3: Department of Economics and Business, University of Cagliari, Cagliari - ITALY

* Corresponding Author E-mail:giampaolo.garzarelli@gmail.com

\author{
ABSTRACT \\ Go to section...
}

Do economic variables operate through the channel of public governance to impact technical (or productive) efficiency in Sub Saharan Africa? We present different stochastic frontier models where technical efficiency is a relation between three economic variables, education, government spending, and trade openness, and three public governance variables, government effectiveness, political stability, and regulatory quality. In all cases, education operates through public governance to improve efficiency while government spending does not.

\section{Keywords}

Government spending, public governance, stochastic frontier, technical efficiency 
Giampaolo Garzarelli*

DiSSE, Sapienza - Università di Roma, Rome, ITALY \& IPEG, SEBS, University of the Witwatersrand, Johannesburg - SOUTH AFRICA

Yasmina Rim Limam

Faculté des Sciences Économiques et de Gestion de Nabeul, Nabeul, TUNISIA \& IPEG, SLBS, University of the Witwatersrand, Johannesburg - SOUTH AFRICA

Stefania P.S. Rossi

Department of Economics and Business, University of Cagliari, Cagliari - ITALY

\section{Public Governance and Productive Efficiency in Sub-Saharan Africa}

Abstract - Do economic variables operate through the channel of public governance to impact technical (or productive) efficiency in Sub Saharan Africa? We present different stochastic frontier models where technical efficiency is a relation between three economic variables, education, government spending, and trade openness, and three public governance variables, government effectiveness, political stability, and regulatory quality. In all cases, education operates through public governance to improve efficiency while government spending does not.

Keywords - Government spending, public governance, stochastic frontier, technical efficiency

FEL Classification Codes - D02, E02, H11, O47, O55

\section{1. - Introduction}

One of the most general messages of Public Choice is that we should consider public governance - the ability to create order through political institutions and public policies as well as the related ability of government to deliver the services ascribed to it at efficient cost [WEBER 1946/1919]; BERTELLI, 2012; GARZARELLI - HoliAN, 2014] - as it is rather than idealize it. This message is perhaps best encapsulated in Buchanan's [1999/1979] dictum that politics is without romance: the idea that like any other

\footnotetext{
* Corresponding Author

E-mail: giampaolo.garzarelli@gmail.com
} 
institutional setting, public governance originates from fallible, selfinterested individuals.

Here, we consider the efficiency of public governance beyond face value. We empirically investigate how three public governance variables (government effectiveness, political stability, and regulatory quality) interact with three economic variables (government spending, trade openess, and human capital) along the margin of technical efficiency. Our sample is 25 countries of Sub Saharan Africa (SSA) over the period 1996-2013. The principal motivation for the sample selection is that previous literature on the Sub Sahara in the main agrees that bad public governance is a fundamental explanans for poor economic performance.

Let us immediately point out the added value of focusing on technical efficiency. The majority of empirical studies considers the contribution of capital and labor accumulation as explanations of output growth. Such procedure leaves a total factor productivity (TFP) residual, that is, a lumpy factor in output growth other than capital and labor accumulation. However, one can decompose TFP into technical efficiency and state of technology: by focusing on output levels, it is empirically possible to analyze short term production efficiency [e.g., DRINE, 2012].

The widely used empirical technique for studying production efficiency is stochastic frontier analysis (SFA) ${ }^{1}$. SFA assumes that, given inputs, a maximum attainable output exists. A country's production will be on the frontier if it uses the inputs efficiently; while it will be within the frontier if it uses the inputs inefficiently. Therefore, the technique allows the decomposition of the error term into two components: random noise and technical inefficiency. Importantly, the frontier is a grass-roots level benchmarking instrument for output: it derives from the data through the best performers of the sample rather than in a top down theoretical manner. As Buchanan [1982] would put it, the frontier is «defined in the process of its emergence», entailing that distance between the frontier and the actual production point can be explained (at least in part) by governance quality.

Results confirm the claim that government does not lead to increased technical efficiency in this sample of countries. The results persist even when all public governance variables are incorporated in the model. Education is found to decrease inefficiency in all governance interactions while trade openness decreases inefficiency (at a significant level) only when it is interacted with political stability.

${ }^{1}$ Compare, among others, Kumbhakar - Ghosh - McGuckin [1991], Reifschneider Stevenson [1991], and Battese - Coelli [1995]. 


\section{2. - Empirical model and variables}

To avoid linear dependence [AHMED - BRAVO URETA, 1996], we adopt a simplified rather than a full translog production function with smooth technological change:

$\ln Y_{i t}=\alpha_{0}+\alpha_{1} \ln K_{i t}+\alpha_{2} \ln L_{i t}+\alpha_{3} T \ln K_{i t}+\alpha_{4} T \ln L_{i t}+\alpha_{5} T+\alpha_{6} T^{2}+v_{i t}-u_{i t},[1]$

where for country $i$ and time $t, Y, K, L$, and $T$ represent total output, private capital, labor and a time trend that accounts for the state of technology; $u_{i t}$ is a non-negative term that accounts for technical inefficiency ${ }^{2}$, and $v_{i t}$ represents random errors.

We assume that a country's distance to the best practice output level is a function of its levels of trade openness $(O P E N)$, government spending $(G O V)$, and human capital $(E D U)$ as well as of governance quality. We use three proxies to capture governance quality: the degrees of government effectiveness $(G E)$, political stability $(P S)$, and regulatory quality $(R Q)$. Our working hypothesis is that all three governance variables are non-neutral in the sense of positively affecting technical efficiency through the selected channels of trade openness, government spending, and human capital.

The nexus between trade openness and economic growth has been widely analyzed in the literature. However, less attention has been dedicated to the relationship between openness and technical efficiency. More pertinent for our investigation, Miller - Upadhyay [2000] find that trade openness has a positive effect on total factor productivity. Chortareas - Desli - Pelagidis [2003] use Data Envelopment Analysis to show that trade openness positively affects technical efficiency in OECD countries.

Government involvement in economic activity affects a country's efficiency by influencing the use of the available inputs and resources. Two major effects of government spending arise from the literature: a positive one, from the spending multiplier, and a negative one, from the crowding out effect. The empirical literature does not provide unanimous evidence about how government spending ultimately affects output growth [EASTERLY-REBELO, 1993; MUELler-STRATTMAN, 2002]. We consider that government spending may indirectly affect output growth through its effect on technical efficiency: infrastructure improvement impacts the way resources are used rather than having a direct effect on output growth.

${ }^{2}$ FRONTIER 4.1, the software package we employ, calculates the regressed coefficients in terms of technical inefficiency, and then gives also the technical efficiency scores from $T E_{i t}=$ $\exp \left(-u_{i t}\right)$. According to context, we will refer to either technical efficiency or technical inefficiency. 
Therefore, the effect of government spending is funneled through an improvement in efficiency.

Additionally, we account for the contribution of human capital on technical efficiency. We assume a direct and positive effect on output, believing that, ceteris paribus, more qualified persons are prone to take better decisions and to employ resources more efficiently. Adkins - Moomaw Savvides [2003] includes human capital among other explanatory variables believed to explain technical efficiency in a sample of developed and developing countries. It finds that human capital strongly and positively affect technical efficiency.

The first governance proxy is the degree of government effectiveness ${ }^{3}$. Governance effectiveness measures how well public services are delivered to the citizens, the quality of policy formulation and implementation, and the degree of independence between public service provision and any form of political pressure.

The second governance proxy is the degree of political stability. A politically stable environment is one where the majority of the population supports the incumbent government and where there is no indication of political unrest, war or conflict. Political instability can harm economic performance through different channels. Consider two. First, political instability can cause the pursuit of myopic gains, for instance through monetary expansion, resulting in inflation. Zimbabwe, which still has to fully recover from a pluri-annual hyperinflationary experience, is a recent illustration. Second, political instability usually dramatically crowds out domestic and foreign private investment. For instance, anticipating a decrease in returns and in the future value of an investment, investors are likely to withdraw from a country. Examples here are numerous, variegated, and ubiquitous in time and place. To mention two recent African ones: the 2002-2007 and 2010-2011 Ivorian Civil Wars, which, among other displacements, even led to the relocation of the African Development Bank from Abidjan to Tunis from 2003 to 2014.

Regulatory quality, our third proxy, measures the degree to which government policies and regulations favor and encourage private sector development and private sector returns. This includes regulation related to price controls, to the ease of doing business, to unfair competition, and to anti-competitive behavior. We expect the quality of regulations to interact with the economic variables to increase technical efficiency.

Based on these considerations, we estimate a stochastic frontier where the

${ }^{3}$ The definitions of our governance proxies are aligned with those of the Worldwide Governance Indicators: http://info.worldbank.org/governance/wgi/index.aspx\#doc. 
technical inefficiency component $-u_{i t}$ from [1] - is modeled according to three specifications where $G O V, O P E N$ and $E D U$ are entered individually and in interaction with each of the three governance variables:

$u_{i t}=\delta_{0}+\delta_{1} G O V+\delta_{2} O P E N+\delta_{3} E D U+\delta_{4} G O V \cdot G E+\delta_{5} O P E N \cdot G E$

$+\delta_{6} E D U \cdot G E+\omega_{i t}$

$u_{i t}=\delta_{0}+\delta_{1} G O V+\delta_{2} O P E N+\delta_{3} E D U+\delta_{4} G O V \cdot P S+\delta_{5} O P E N \cdot P S$

$+\delta_{6} E D U \cdot P S+\omega_{i t}$

$u_{i t}=\delta_{0}+\delta_{1} G O V+\delta_{2} O P E N+\delta_{3} E D U+\delta_{4} G O V \cdot R Q+\delta_{5} O P E N \cdot R Q$

$+\delta_{6} E D U \cdot R Q+\omega_{i t}$,

where $\omega_{i t}$ is a random error.

In other words, we estimate three versions of equation [1] - namely, of the stochastic frontier - for 25 SSA countries over the 1996-2013 period where technical inefficiency is modeled in turn as in [2], [3], and [4]. The complete list of countries appears in Table A1 in the Appendix. The final estimated frontiers are reported as specification I, II, and $\mathrm{III}^{4}$.

\section{3. - Data and empirical results}

Available databases do not provide time series data on the stock of physical capital and the information is even less reliable when it comes to SSA countries. Consequently, we build our own capital stock series from data on fixed capital formation and using the perpetual inventory method [HARBERGER, 1978]. To compute the initial capital stock, we follow King Levine [1994], which uses steady state values to find the stock of capital stock. Data on fixed capital formation, $Y, G O V$ and $O P E N$, are retrieved from the World Development Indicators (WDI) ${ }^{5}$. Human capital $(E D U)$ is measured as the average number of years of education in the population aged 25 and above and comes from the Barro - Lee Educational Attainment Dataset ${ }^{6}$. Finally, the governance variables are from the Worldwide Governance Indicators (WGI), which provide aggregate and individual

${ }^{4}$ In all specifications we find that a simplified translog is a better fit than a Cobb Douglas, and that a frontier model is a better fit than Ordinary Least Squares.

${ }^{5} \mathrm{http} / /$ data.worldbank.org/data-catalog/world-development-indicators.

${ }^{6}$ Barro - Lee contains data at 5 -year intervals. Since we need yearly data, we use the 5 -year information to fill in the missing data within the same interval. http://www.barrolee.com/. 
indicators for 215 countries and territories over the period 1996-2013 for different public governance dimensions. The WGI indexes data from -2.5 (lowest score) to 2.5 (highest score). Table 1 summarizes the statistics for all variables.

Table 1 - Data description

\begin{tabular}{|c|c|c|c|c|c|}
\hline Variable & Minimum & Maximum & Mean & Median & Standard deviation \\
\hline$Y$ & $\begin{array}{c}0.62 \\
\text { (The Giambia) }\end{array}$ & $\begin{array}{c}255 \\
\text { (South Africa) }\end{array}$ & 16.60 & 6.38 & 50 \\
\hline$K$ & $\begin{array}{c}0.41 \\
\text { (The Cambia) }\end{array}$ & $\begin{array}{c}207 \\
\text { (South Africa) }\end{array}$ & 13.36 & 3.79 & 40.62 \\
\hline$L$ & $\begin{array}{c}0.28 \\
\text { (Swaziland) }\end{array}$ & $\begin{array}{c}19.30 \\
\text { (Dem Rep Congo) }\end{array}$ & 5.64 & 5.49 & 5.50 \\
\hline$G E$ & $\begin{array}{c}-1.73 \\
\text { (Dem Rep Congo) }\end{array}$ & $\begin{array}{c}0.63 \\
\text { (Mauritius) }\end{array}$ & -0.56 & -0.54 & 0.61 \\
\hline PS & $\begin{array}{c}-2.36 \\
\text { (Dem Rep Congo) }\end{array}$ & $\begin{array}{c}0.95 \\
\text { (Botswana) }\end{array}$ & -0.43 & -0.40 & 0.83 \\
\hline$R Q$ & $\begin{array}{c}-1.73 \\
\text { (Zimbabwe) }\end{array}$ & $\begin{array}{c}0.63 \\
\text { (Botswana) }\end{array}$ & -0.48 & -0.43 & 0.59 \\
\hline GOV & $\begin{array}{c}7.84 \\
\text { (Dem Rep Congo) }\end{array}$ & $\begin{array}{c}36.16 \\
\text { (Lesotho) }\end{array}$ & 15.10 & 13.88 & 5.89 \\
\hline$O P E N$ & $\begin{array}{c}35.48 \\
\text { (Burundi) }\end{array}$ & $\begin{array}{c}171.69 \\
\text { (Lesotho) }\end{array}$ & 71.46 & 63.38 & 36.34 \\
\hline$E D U$ & $\begin{array}{c}0.99 \\
\text { (Mozambique) }\end{array}$ & $\begin{array}{c}7.89 \\
\text { (Botswana) }\end{array}$ & 4.25 & 4.06 & 2.11 \\
\hline
\end{tabular}

Notes: $Y$ and $K$ are in US $\$$ billions. $L$ is the labor force in millions. GE, $P S$ and $Q R$ are index numbers. $E D U$ measures the average number of years of education. GOV and $O P E N$ are measured in percentage of GDP. Number of countries $N=25$.

Table 2 displays a brief summary of the technical efficiency scores obtained from our three specifications for the top two and bottom two countries. The more detailed results on per country technical efficiency are found in the Appendix. Results indicate that the efficiency scores are quite stable throughout the sample and across the three specifications as shown by the mean values and the standard deviations (only 10 percent deviation from the mean). 
Table 2 - Technical efficiency ranking, 1996-2013

\begin{tabular}{|c|c|c|c|c|}
\hline Specification & Two Lowest Efficiencies & Two Highest efficiencies & Me:tn & Standard deviation \\
\hline 1 & $\begin{array}{c}0.4458 \\
\text { (Lesotho) } \\
0.7021 \\
\text { (Zimbabwe) }\end{array}$ & $\begin{array}{c}0.9800 \\
\text { (South Africa) } \\
0.9731 \\
\text { (Mauritius) }\end{array}$ & 0.897 & 0.109 \\
\hline II & $\begin{array}{c}0.4726 \\
\text { (Lesotho) } \\
0.7906 \\
\text { (Zimbabwe) }\end{array}$ & $\begin{array}{c}0.9742 \\
\text { (Mauritius) } \\
\\
0.9818 \\
\text { (Rwanda) }\end{array}$ & 0.927 & 0.102 \\
\hline III & $\begin{array}{c}0.4487 \\
\text { (Lesotho) } \\
\\
0.6897 \\
\text { (Zimbabwe) }\end{array}$ & $\begin{array}{c}0.9747 \\
\text { (South Africa) } \\
0.9738 \\
\text { (Mauritius) }\end{array}$ & 0.914 & 0.111 \\
\hline
\end{tabular}

Interestingly, Lesotho is consistently ranked the least efficient followed by Zimbabwe, whereas Mauritius, Rwanda, and South Africa alternate for the first and second highest ranks. Taking a closer look at the efficiency ranking, we notice that Lesotho and Zimbabwe widely deviate from the mean while the top countries' efficiencies stand slightly above the mean.

These results are consistent with the countries' macroeconomic indicators. Lesotho is a small economy landlocked within the borders of South Africa. It is largely poor and rural, and is plagued by significantly high unemployment. HIV/Aids is one of the biggest health issues affecting especially the youth ${ }^{7}$. Zimbabwe as the second most inefficient country can be explained by the high levels of corruption, economic uncertainty, and political instability that the country has been experiencing since about 2000 . According to the 2013-2014 Global Competitiveness Report, from a total 148 countries, Zimbabwe ranks 112 when it comes to the efficiency of government spending, 117 in judicial independence, and 137 in public trust in politicians ${ }^{8}$.

7 African Economic Outlook (2014), available at http://www.afdb.org/en/countries/ southern-africa/lesotho/lesotho-economic-outlook/.

${ }^{8} \mathrm{http}: / /$ www3.weforum.org/docs/WEF_GlobalCompetitivenessReport_2013-14.pdf. 
The positive results of Mauritius are not unexpected. The 2013-2014 Global Competitiveness Report ranks the country's financial institutions second in SSA following South Africa. The past few years saw the country emerge as one of the region's top performing economies, especially after it successfully withstood the global financial crisis. Its sound macroeconomic policies, a well-developed financial system, and reliable institutions made it one of the best business environments in SSA $^{9}$.

The fact that Rwanda ranks among the most efficient in SSA is consistent with findings of other efficiency studies, such as those of the World Bank about Doing Business ${ }^{10}$. Since the 1994 genocide, Rwanda has put remarkable effort in rebuilding its economy. Among other things, these efforts consisted in trying to re-establish a business and investment friendly economy. The country achieved a remarkable average GDP growth of 7-8 percent over 2003-2013.

The results about South Africa are also not surprising. The country is extremely rich in natural resources and is endowed with one of the best infrastructures in SSA. It tops the list of African countries when it comes to competitiveness, innovative capability, and quality of institutions. South Africa is also the most innovative in SSA. In addition to being endowed with the most developed and well-functioning financial market in the region, it has the most reliable institutions, topping the list in terms of property rights and in the efficiency of the legal framework ${ }^{11}$.

Table 3 displays the results of the stochastic frontier estimations. Within each specification, the first six lines display the coefficients of the estimated frontiers based on [1], whereas the next lines exhibit the coefficients of the equations explaining technical inefficiency based on specification I, II, and III. The last three rows of Table 3 report inefficiency statistics - the inefficiency variance, $\sigma_{u}{ }^{2}$, and the inefficiency indicator, $\gamma$, which measures the percentage of the error term that is explained by inefficiency - and the log-likelihood.

Considering the coefficients of the production function, we notice that the coefficient of $\ln K$ is positive and highly significant in all three specifications, indicating that capital formation has a positive impact on output. The coefficient of $\ln L$ appears to be positive but not significant. However, when interacted with technological change, $L$ becomes highly significant in all cases. This result seems to indicate that technological

\footnotetext{
9 African Economic Outlook (2014).

${ }^{10} \mathrm{http}: / /$ www.doingbusiness.org/.

${ }^{11} \mathrm{http} / /$ www3.weforum.org/docs/WEF_GlobalCompetitivenessReport_2012-13.pdf.
} 
Table 3 - Stochastic frontier and tecbnical efficiency estimation with interactions, $\operatorname{Ln}(Y)$ dependent variable

\begin{tabular}{|c|c|c|c|c|}
\hline \multirow[b]{2}{*}{ Parameter } & \multirow[b]{2}{*}{ Variable } & \multicolumn{3}{|c|}{ Specification } \\
\hline & & I & II & III \\
\hline$a_{1}$ & Frontier Intercept & 1.156 & $0.984 * 2 \%$ & $1.16 .3: 4,4$ \\
\hline$\alpha_{1}$ & $\ln K^{\prime}$ & $0.900^{*} \times$ & $0.910^{\text {***: }}$ & $0.910 * * *$ \\
\hline$\alpha$ & $\ln L$ & 0.029 & 0.031 & 0.021 \\
\hline$\epsilon_{3}$ & $\ln K$ & $-0.004 * \cdots * *$ & $-0.00 .3^{*} * *$ & $-0.004^{*: 1}$ \\
\hline$a_{4}$ & $\operatorname{Th} L$ & $0.007 \%$ & $0.006 \% * 2 *$ & 0.0078 \\
\hline$\alpha_{5}$ & $T$ & 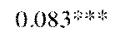 & $0.064^{* * *}$ & 0.076 \\
\hline$a_{t_{r}}$ & $T^{2}$ & 0.001 & 0.001 & $0.001 \%$ \\
\hline$\partial_{0}$ & Itefficiency intercept & 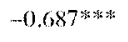 & 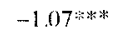 & $-0.818^{*}$ \\
\hline$\delta_{1}$ & GOV & 0.051 & 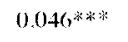 & $0.054: \div 3: 5$ \\
\hline$\delta$ & $O P E N$ & $0.0011^{* 1 * * *}$ & 0.001 & 0.001 \\
\hline$\delta_{3}$ & $E D U$ & $-0.082^{* * * * k}$ & -0.09 & $-0.074^{* * * *}$ \\
\hline$\delta_{4}$ & $G O V G E$ & $0.026 \%$ & & \\
\hline$\delta_{s}$ & $O P E N \cdot G E$ & $0.002 * * * *$ & & \\
\hline$\delta_{\epsilon_{1}}$ & $E D U \cdot G E$ & $-0.189 * * * *$ & & \\
\hline$\delta_{4}$ & $G O V \cdot P S$ & & $0.028 * * *$ & \\
\hline$d_{5}$ & OPEN.PS & & $-0.004 * * *$ & \\
\hline$\delta_{6}$ & $E D U \cdot P S$ & & $-0.080^{* * * * * 1}$ & \\
\hline$\delta_{4}$ & $G O V \cdot R Q$ & & & $0.027^{x+k}$ \\
\hline$\delta_{s}$ & $O P E N \cdot R Q$ & & & -0.001 \\
\hline$\delta_{,}$ & $E D U \cdot R Q$ & & & -0.117 \\
\hline$\sigma_{i}^{2}$ & Inefliciency variance & $0.047^{* * 2 * k}$ & $0.50^{*}$ 冰 & $0.0477^{* 3 * 3}$ \\
\hline$\gamma$ & Inefficiency indicator & $0.429^{\text {: }: * * * * *}$ & $0.352 \%$ & $0.414^{2: 3 *:}$ \\
\hline Log-likelihood & & 139.68 & $108 .+1$ & $1+3.6(6)$ \\
\hline
\end{tabular}

Notes: ${ }^{* * *}$ Significant at the $1 \% ;{ }^{* \star}$ Significant at the $5 \% ;{ }^{*}$ Significant at the $10 \%$. Numbers in parentheses indicate t-statistics. Number of countries $N=25$. Number of periods $T=18$. 
change is labor augmenting. The coefficient of $T$ is positive and always significant at different levels, which seems to suggest that for African countries technological change (mainly imported technology in the context of developing countries), has a positive impact on output. Surprisingly, the coefficient of $T \ln K$ turns out to be negative and significant across all specifications. This may indicate that imported technology in combination with the capital stock has not been converted into a corresponding output. One explanation could be that in this sample of SSA countries the available capital stock presents outdated and obsolete standards that are not able to generate additional output in combination with the imported technology [LIMAM - MiLlER, 2004].

The coefficients of the technical efficiency components tell an equally interesting story. The coefficient on trade openness turns out positive in all specifications but is significant only in specification I, indicating that in this case openness does not seem to increase efficiency. One explanation can be the following: the low quality of public governance displayed by SSA countries may prevent the efficient absorption of trade revenues in production.

The coefficient of $E D U$ appears to be always negative and is highly significant in two out of three cases. Consistently with the predictions of previous literature, this implies that increasing the level of education seems to decrease inefficiency.

Most interestingly, the $G O V$ coefficient is always positive and highly significant in two cases, suggesting that government spending increases inefficiency. This evidence seems to support the crowding out theory, which hints that government spending takes resources away from more productive private investment, decreasing the level of private investment. If private investment has higher returns than public investment, the result will be a decrease in aggregate output.

To further study the effect of the control variables on technical efficiency, we next analyze whether $G O V, O P E N$ and $E D U$ affect technical inefficiency through their interaction with the governance variables. We expect the control variables to perform better when interacted with governance quality. The evidence on the interacted variables seems to corroborate the results obtained above. Specifically, results show that when interacted with $E D U$, all the control variables have negative and highly significant coefficients. These results support the notion that investment in human capital in combination with a good governance increases productive efficiency.

Results on the interactions between $O P E N$ and the governance variables indicate that $O P E N$ interacts with $P S$ to increase efficiency. This result indicates that trade openness, when interacted with a stable political 
environment, is able to generate benefits in productivity. The interaction with $R Q$, even if negative, is not significant.

Finally, the interaction terms between $G O V$ and the governance variables all have positive and strongly significant coefficients. This result confirms the hypothesis that government spending increases technical inefficiency, and consequently slows output growth. Moreover, it indicates, all else equal, that increasing public spending in countries characterized by an inefficient public sector takes away productive resources from other sectors.

\section{4. - Conclusion}

We analyze economic variables and public governance in relation to technical efficiency in SSA. We find that when not interacted with public governance, only education has a positive effect on technical efficiency. Further, education keeps its strong, positive effect on technical efficiency when interacted with government effectiveness and regulatory quality. Trade openness interacts with political stability to decrease inefficiency. Finally, government spending does not improve technical efficiency either by itself or when interacted with public governance. Especially this last result renders the notion that public spending automatically generates output growth at zero cost less compelling. 
Appendix

Here we report the list of 25 SSA countries as well as the total technical efficiency averages over the period 1996-2013 as obtained from the three specifications.

Table A1 - Country and total technical efficiency averages

\begin{tabular}{lccc}
\hline & \multicolumn{3}{c}{ Specification } \\
\hline Country & I & II & III \\
Benin & 0.9324 & 0.9689 & 0.9485 \\
Botswana & 0.9259 & 0.9351 & 0.9175 \\
Burundi & 0.8585 & 0.9603 & 0.8908 \\
Cameroon & 0.9277 & 0.9678 & 0.9592 \\
Central African Republic & 0.9373 & 0.9688 & 0.9650 \\
Democratic Republic of the Congo & 0.8835 & 0.8795 & 0.9300 \\
Ghana & 0.9545 & 0.9582 & 0.9595 \\
Kenya & 0.9041 & 0.9047 & 0.9524 \\
Lesotho & 0.4458 & 0.4726 & 0.4487 \\
Malawi & 0.8769 & 0.9370 & 0.9025 \\
Mali & 0.9496 & 0.9640 & 0.9421 \\
Mauritius & 0.9731 & 0.9818 & 0.9738 \\
Mozambique & 0.9519 & 0.9666 & 0.9534 \\
Namibia & 0.9188 & 0.9344 & 0.9163 \\
Niger & 0.9217 & 0.9550 & 0.9231 \\
Rwanda & 0.9559 & 0.9742 & 0.9651 \\
Senegal & 0.9269 & 0.9537 & 0.9445 \\
Sierra Leone & 0.9563 & 0.9739 & 0.9656 \\
South Africa & 0.9800 & 0.9535 & 0.9747 \\
Swaziland & 0.9102 & 0.9373 & 0.9318 \\
The Gambia & 0.9478 & 0.9738 & 0.9581 \\
Togo & 0.8459 & 0.9491 & 0.9341 \\
Uganda & 0.9329 & 0.9578 & 0.9569 \\
Zimbabwe & 0.7021 & 0.7906 & 0.6897 \\
\hline Total average & 0.897 & 0.927 & 0.914 \\
\hline & & & \\
\hline
\end{tabular}




\section{REFERENCES}

Adkins, L. C. - Moomaw, R. L. - SAvvides, A., 2002, «Institutions, Freedom, and Technical Efficiency», Soutbern Economic 7ournal, 69, pp. 92-108.

AhMAD, M. - Bravo-URETA, B. E., 1996, «Technical Efficiency Measures for Dairy Farms Using Panel Data: A Comparison of Alternative Model Specifications», Fournal of Productivity Analysis, 7, pp. 399-415.

BATTESe, G. E. - Coelli, T.J., 1995, «A Model for Technical Inefficiency Effects in a Stochastic Frontier Production Function for Panel Data», Empirical Economics, 20, pp. 325-332.

BerTelli, A. M., 2012, The Political Economy of Public Sector Governance, New York, Cambridge University Press.

Buchanan, J. M., 1979/1999, «Politics Without Romance: A Sketch of Positive Public Choice Theory and Its Normative Implications», in BuCHANAN, J. M., The Logical Foundations of Constitutional Liberty, Volume 1 of The Collected Works of James M. Bucbanan, Indianapolis, Liberty Fund, pp. 45-59, originally published in 1979.

Buchanan, J. M., 1982, «Order Defined in the Process of Its Emergence», Literature of Liberty, 5, p. 5. http://www.econlib.org/library/Essays/LtrLbrty/ bryRF1.html.

Chortareas, G. E. - Desli, E. - Pelagidis, T., 2003, «Trade Openness and Aggregate Productive Efficiency», European Research Studies, 6, pp. 188-200.

DrINE, I., 2012, «Institutions, Governance and Technology Catch-up in North Africa», Economic Modelling, 29, pp. 2155-2162.

EASTERLy, W. - REBelO, S., 1993, «Marginal Income Tax Rates and Economic Growth in Developing Countries», European Economic Review, 37, pp. 409-417.

Garzarelli, G. - Holian, M. J., 2014, «Guns, Parchment, and the Problem of Governance», Review of Austrian Economics, 27, pp. 71-80.

HaRberger, A. C., 1978, «Perspectives on Capital and Technology in Less Developed Countries», in ARTIS, M. J. - NOBAY, A. R. (eds), Contemporary Economic Analysis, London, Croom Helm, pp. 15-40 (The Frank Paish Lecture presented at the 1977 meetings of the U.K. Association of University Teachers of Economics, Swansea).

KING, R. J. - LEVINE, R., 1994, «Capital Fundamentalism, Economic Development and Economic Growth», Carnegie-Rocbester Conference Series on Public Policy, 40, pp. 259-292.

KumbhaKar, S. C. - Soumendra, G. - MCGuckin, J. T., 1991, «A Generalized Production Frontier Approach for Estimating Determinants of Inefficiency in U.S. Dairy Farms», 7ournal of Business \&o Economic Statistics, 9, pp. 279-286.

LimAM, Y. R. - MilleR, S. M., 2004, Explaining Economic Growth: Factor Accumulation, Total Factor Productivity Growth, and Production Efficiency Improvement, Working paper 2004-20, University of Connecticut, Department of Economics.

Miller, S. M. - Upadhyay, M. P., 2002, Total Factor Productivity, Human Capital and Outward Orientation: Differences by Stage of Development and Geograpbic 
Regions, Working paper 2002-33, University of Connecticut, Department of Economics.

Mueller, D. C. - Strattman, T., 2003, «The Economic Effects of Democratic Participation», Fournal of Public Economics, 87, pp. 2129-2155.

ReirschneIder, D. - Stevenson, R., 1991, «Systematic Departures from the Frontier: A Framework for the Analysis of Firm Inefficiency», International Economic Review, 32, pp. 715-723.

RoDRIK, D., 2008, «Understanding South Africa's Economic Puzzles», Economics of Transition, 16, pp. 769-797.

Weber, M., 1919/1946, «Politics as Vocation», in From Max Weber: Essays in Sociology, translated, edited and introduced by Gerth, H. H. - Mills, C. W., New York, Oxford University Press, pp. 77-128. Originally published in German in 1919. 